\title{
Dispersion of tongka langit banana in Buru and Seram, Maluku Province, Indonesia, based on topographic and climate factors
}

\author{
HALVINA GRASELA SAIYA ${ }^{1}$, ADRIANA HIARIEJ ${ }^{2, \bullet}$, ANNEKE PESIK ${ }^{2}$, ELIZABETH KAYA ${ }^{3}$, \\ MEITTY LOUISE HEHANUSSA ${ }^{3}$, FERAD PUTURUHU ${ }^{3}$ \\ ${ }^{1}$ School of Environmental Science, Universitas Indonesia. Jl. Salemba Raya No. 4, Jakarta Pusat 10430, Jakarta, Indonesia \\ ${ }^{2}$ Faculty of Mathematics and Natural Sciences, Universitas Pattimura. J1. Ir. M. Putuhena, Kampus Poka, Ambon 97116, Maluku, Indonesia. \\ Tel.: +62-911-3825203, Fax.: +62-911-3825204, `email: hiariejdn@ gmail.com \\ ${ }^{3}$ Faculty of Agriculture, Universitas Pattimura. J1. Ir. M. Putuhena, Kampus Poka, Ambon 97116, Maluku, Indonesia
}

Manuscript received: 23 February 2020. Revision accepted: 15 April 2020.

\begin{abstract}
Saiya HG, Hiariej A, Pesik A, Kaya E, Hehanussa ML, Puturuhu F. 2020. Dispersion of tongka langit banana in Buru and Seram, Maluku Province, Indonesia, based on topographic and climate factors. Biodiversitas 21: 2035-2046. The aim of this research is to understand the dispersion of tongka langit banana as one of the important endemic species in Maluku and also to know the topographic and climate factors hypothetically influencing the dispersion of tongka langit banana. The associated environmental factors are an initial approach that can be used to assess why the species only exists in certain locations. The data of coordinates were collected from survey activity; meanwhile, the slope and contour data were from the Shuttle Radar Topographic Mission (SRTM); and the climate data were from Meteorology, Climatology, and Geophysical Agency through statistic data publication. Then, all data were analyzed using Remote Sensing and GIS methods. The results showed that in Buru Island, tongka langit bananas were found in four locations, with climate condition was rather wet and found on slope grade of 0-8\% and 8-15\%. Whereas in Seram Island, tongka langit bananas were found in fifteen locations, with wet climate conditions, and on the same condition of slope as those found in Buru island.
\end{abstract}

Keywords: Dispersion, Seram and Buru island, slope, tongka langit Banana, topography and climate factors

\section{INTRODUCTION}

Banana is a type of fruit and a farming commodity known widely by societies living in tropical areas (De Langhe and de Maret 1999; Padam et al. 2014) like Indonesia. Almost all parts of banana trees are useful (Drapal et al. 2019; Yusuf et al. 2019) starting from the root, stem, leaf, flower, fruit, and even its peel. Banana fruit is a source of vitamin B6, fiber, potassium, magnesium, vitamin $\mathrm{C}$, and manganese. It is also good for the health of heart, digestion system, and as a food alternative for those who wish to control their weight (Bertoia et al. 2015; Pereira and Maraschin 2015). As a country with high biodiversity in the world, Indonesia experiences growth of banana production about as much as 11.6 gigagrams for the production in 2017 to 2018 (Indonesia Central Statistics Agency 2017). However, this calculation is accomplished to only types of banana commodity which are frequently consumed. Due to its frequent consumption, some of those types can often be found in the markets which enable calculation to be carried out. Several types of banana such as pisang raja or Latundan banana (dessert banana) and pisang abu-abu, pisang susu, Saba banana, and pisang tanduk or (cooking/plantain bananas) are often consumed by the people from Maluku Province, Indonesia. Indonesia as one of the countries with mega biodiversity owns many varieties of banana and not all types of banana are cultivated and can be calculated their productivity, since some bananas only exist in certain areas.

In general, bananas are classified as edible banana and wild banana (Horry and Jay 1988; Arvanitoyannis et al. 2015). Edible bananas usually grow or are planted around the house yard or garden, while wild bananas are found in forests. In a deeper investigation, some kinds of banana are endemic, meaning they can only be found in certain areas (Ploetz and Pegg 1997; De Langhe and de Maret 1999; Latupeirissa et al. 2014). Since there are a great number of banana varieties, mapping plays a significant role as it is not only limited for identification of variety and distribution (Poole et al. 2015; Romanov et al. 2017) but also for investigating their genetic relationships among levels of taxon (Baggio et al. 2017; Wango et al. 2019) and examining the comparison of their habitats (Croce et al. 2019; Woellner and Wagner 2019). In the end, mapping can be used to determine ideal habitats required for cultivation of a species. For a wider conservation goal regarding the distribution of plant species, environment variables (Franklin 1995) like topography and climate (Amos et al. 2010; Jin et al. 2013) can provide more detailed analysis outcome for sustainable conservation planning.

One of banana varieties grown endemically in Maluku archipelago is tongka langit (or sometimes spelling as tongkat langit) banana (Musa troglodytarum L.) (Latupeirissa et al. 2014; Hiariej and Karuwal 2015). Tongka langit banana belongs to the genus of Musa with 
the tree height between 1.5-6.0 m, stem with no wax, sap on runny stem, orange, and purple sap, and dark green stalk (Samson et al. 2013; Latupeirissa et al. 2014). The male bud of banana trees with short fruits stays until it is harvested while for those with long banana fruits the male bud is fall. The morphological characters of tongka langit banana from Maluku are varied in bunch shapes, fruit shapes, fruit sizes (long and short), and fruit colors which cause this particular type of banana different from other bananas. For long and short types of banana, the color of the fruit peel before they are ripe is the same; green. After they ripen, they have various colors like brownish red, blackish-red, yellow, and orange. The different colors of the peel and flesh on tongka langit banana show the beta carotene content (Samson et al. 2013; Hiariej et al. 2015).

The temperature for bananas is generally the same for all types of banana ranging from $30-32^{\circ} \mathrm{C}$ with air humidity of $28-30 \%$, soil $\mathrm{pH}$ of $5.2-7.5$, soil salinity of $0.21-1.5 \mathrm{mS}$, organic C content of $1.83-5.23 \%$. Phosphor content in the soil varies starting from $2.22-23.19 \%$. Soil texture is sandy clay and dusty clay. Banana grows well both in lowlands and highlands (Hiariej and Karuwal 2015). Topography and climate are two of the most basic factors that determine the diversity of plant species (Gibson and Hulbert 1987; Severin et al. 2015). In addition, climate and topography can also be factors in the emergence of an abundance of species, even the emergence of endemism of a species (Severin et al. 2015). The topography of an area is closely related to the type of soil, rocks and altitude, temperature and humidity of the environment. These determine the type of soil texture in which plants will grow, as well as physical factors that also influence the plant growth (Campbell and Norman 1998; Hillel 2008). Topography cannot be separated from climatic conditions that also determine the temperature and humidity of the environment. This environmental information is required to examine the spread of a species. This can be approached by the remote sensing approach and geographic information systems. (Lillesand and Kiefer 2004) states that remote sensing method is a satellite technique which gathers information about certain areas/objects without direct contact with the areas/objects, and the characteristics of the data are covering quite large areas, reaching the areas which are terrestrially difficult to grasp, and recording the whole objects in unity and with no modification. This method is combined with GIS (Geographic Information Systems) method to obtain information on the topography of Buru Island and Seram Island.

Geographic Information Systems (GIS) is a computerbased information system to save and manage geographical information, and it is a combination of hardware, software, geographical data and human resources in which all those components become a system working to input, process and display geographical-based data (Aronoff 1991; ESRI 1999). The data obtained in GIS are those spatial data with geographical orientation. Those refer to the data which possess location information with certain coordinates as the basic reference. Thus, spatial data cultivation using GIS can directly provide information on location conditions, trends, patterns, and models. This ability differentiates GIS from any other information system. GIS area analysis is an accurate analysis model as GIS presents data with spatial perspective which causes area coverage, whether small or big, to be visible and well mapped (Ahern 1999). This fact is highly correlated with the objective of species dispersion mapping or biogeography.

In qualitative manner, for example, it states that certain species are distributed in a number of islands, provinces, cities, or other regions; while in quantitative manner, it mentions the number of species in certain region, its density level, the number of male and female individuals, and other similar data. Qualitative and quantitative data can be displayed in GIS. The data display will show both quantitative and qualitative data. Therefore, some relevant information about a species is available only by looking at the mapping (Leitch and Miller 2017). In this research, spatial analysis is utilized to map the species of tongka langit banana in an effort to find out the dispersion of tongka langit banana as one of important endemic species in Maluku and also to know the topographic and climate factors that hypothetically influence such dispersion on tongka langit banana.

\section{MATERIALS AND METHODS}

This research applied a survey method combined with Geographic Information System (GIS) and remote sensing. For data collection, the survey was accomplished in October 2018 located in Buru Island District (North Buru), South Buru District, and several districts in Seram Island namely Central Maluku, Eastern Seram, and Western Seram. The starting point of the study location and tracking plan for the survey was made by an initial observation conducted by a number of researchers in some locations in Buru Island and Seram Island where each researcher had had an experience with the sites. Information was also gathered from local residents.

After the survey, we conducted a data analysis as follows: data of coordinate were transferred and classified which resulted in dispersion mapping of tongka langit banana. Secondary data from satellite imagery and related institutions were also obtained which then resulted in several thematic maps regarding topography appearance and climate condition. The equipment and stuff used are Global Positioning System (GPS) Garmin type 78S; compass; Garmin BaseCamp; ArcGIS 10.3 ESRI License; Microsoft Excel; topography data of slope and contour lines obtained from SRTM image (Shuttle Radar Topography Mission); climate data of rainfall, rainy day, temperature, humidity, wet months, dry months and humid months from Meteorology, Climatology, and Geophysical Agency through statistic data publication from each district, completed with data of Rupa Bumi Indonesia or Indonesian Earth Shape with a scale of 1:50,000 from Badan Informasi Geospasial Republik Indonesia through the Center of Spatial Data Infrastructure Development, Pattimura University, Ambon, Indonesia.

The primary data began with data transferred from GPS using Garmin BaseCamp, and continued by a coordinate 
data classification using Microsoft Excel. The coordinates were then mapped using ArcGIS 10.3 by combining data display of Rupa Bumi Indonesia or Indonesian Topographic Map as a guide of region boundary administration. Secondary data management using remote sensing technique is presented below: (i) Slope data were gained by an extract and a mask on DEM SRTM image according to the area of interest, and then the slope and reclassification were applied on ArcToolbox by classifying slopes according to official classification from Agriculture Department by generalizing unit of data into percentage. (ii) Contour data were obtained using DEM SRTM image data to generate information on slopes, but the command used to extract contour data was Contour command on ArcToolbox. (iii) Data on rainfall, rainy day, temperature, humidity, wet months, dry months and humid months in the form of pure numeric data were first prepared in the spreadsheet format for then each datum was calculated using Mohr criteria and Q formula of Schmidt-Fergusson climate classification (Lakitan 2002). The data prepared are secondary data obtained from BMKG (Balai Meteorologi, Klimatologi dan Geofisika or Meteorology, Climatology, and Geophysical Agency), through annual statistical report data.

$\mathrm{Q}$ value is calculated by the number of dry months divided by the number of wet months. with the value of $Q$ referring to the Schmidt-Ferguson climate classification which is divided into 8 classifications, as follows (Table 1).

\section{RESULTS AND DISCUSSIONS}

\section{Dispersion of tongka langit banana}

The result of survey and data analysis from primary data produces the dispersion map of tongka langit Banana in Buru Island (Table 2, Figure 1) and Seram Island (Table 2, Figure 2), in the Province of Maluku, Indonesia.

The two maps were yielded from primary data in the form of observation and tracking coordinate points in targeted areas. From the map, it can be seen that the subdistricts of Waeapo, Leksula, and Namrole are the locations of the discovery of tongka langit banana in Buru Island. Except for Leksula Sub-district, positive information was gathered from a number of informants (market players) of traditional markets in Namrole, Waeapo and Namlea all of whom stated that the biggest banana production in Buru Island was also supplied by Leksula, and tongka langit banana could also be seen in Leksula. Meanwhile, tongka langit banana dispersion in Seram Island almost happens in all areas covering Kairatu, Northwest Seram, Amahai, Tehoru, North Seram, Siwalalat, Teon Nila Serua, Masohi City and Bula. Except for Werinama Sub-district, positive information also was gathered from a number of informants (farmers in Sub-district of Siwalalat) who stated that they obtained tongka langit banana seedlings from the Subdistrict of Werinama. There is also possibility that tongka langit banana located in other regions like Taniwel and other places, but the survey could not reach the other regions due to limited time. Table 2 . shows the location of coordinates for the discovery of tongka langit banana in Buru Island and Seram Island, using the UTM (Universal Transverse Mercator) coordinate system.

\section{Slope and contour}

Analysis of the Shuttle Radar Topography Mission (SRTM) satellite data collected from the Buru and Seram Island, showed slope variations from flat condition as much as $0-8 \%$ to very steep conditions as much as $>40 \%$ (Figure 3 and 4$)$.

The Shuttle Radar Topography Mission satellite data were also taken to be processed to become contour data, showing that the contour condition of both Buru and Seram Islands had contour variations from contour class under $300 \mathrm{~m}$ asl (meters above sea level) up to contour class above $2.100 \mathrm{~m}$ asl (Figures 5 and 6).

\section{Climate}

Based on statistic report (2015-2019) with the data from BMKG (Balai Meteorologi, Klimatologi dan Geofisika or Meteorology, Climatology, and Geophysical Agency) from 2014 to 2018 (Tables 4 and 5). The climate data of North Buru and South Buru are only obtained from one location of the same BMKG weather station, that is the weather station in Namlea (Table 3). Meanwhile, the climate data for Seram Island were obtained from three different BMKG weather stations, namely: BMKG weather station in Amahai for Central Maluku; BMKG weather station in Kairatu for West Seram; and, BMKG weather station in Geser for Eastern Seram (Table 4). The rainfall, rainy day, temperature, humidity, wet months, dry months and humid months of the two locations are presented in Tables 4 and 5.

Table 1. Schmidt-Ferguson climate classification (Lakitan 2002)

\begin{tabular}{|c|c|c|c|}
\hline Climate & $Q$ value & Character & Information \\
\hline A & $0-0.143$ & Really wet & Tropical rainforest \\
\hline B & $0.143-0.333$ & Wet & Tropical rainforest \\
\hline $\mathrm{C}$ & $0.333-0.6$ & Rather wet & $\begin{array}{l}\text { Forests, leaves fall } \\
\text { during the dry season }\end{array}$ \\
\hline $\mathrm{D}$ & $0.6-1$ & Moderate & Season forest \\
\hline $\mathrm{E}$ & $1-1.67$ & A little dry & Savanna forest \\
\hline $\mathrm{F}$ & $1.67-3$ & Dry & Savanna forest \\
\hline G & $3-7$ & Very dry & Grassland \\
\hline $\mathrm{H}$ & $>7$ & Extreme & Grassland \\
\hline
\end{tabular}




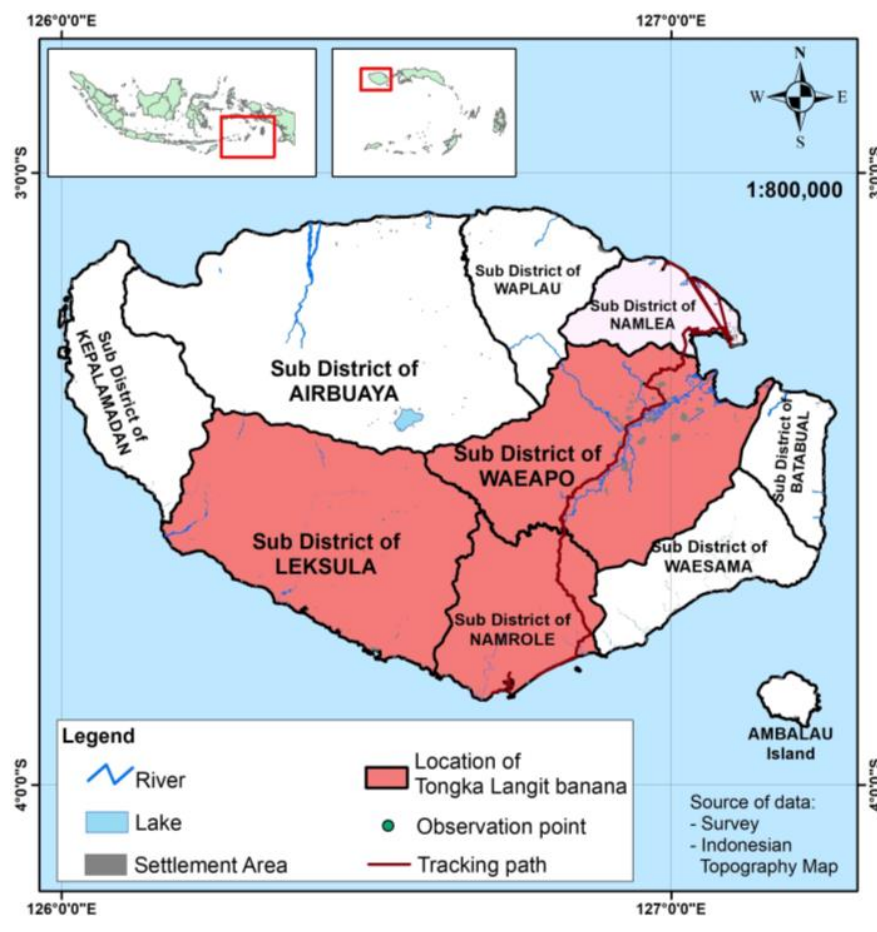

Figure 1. Tongka langit banana dispersion map in Buru Island

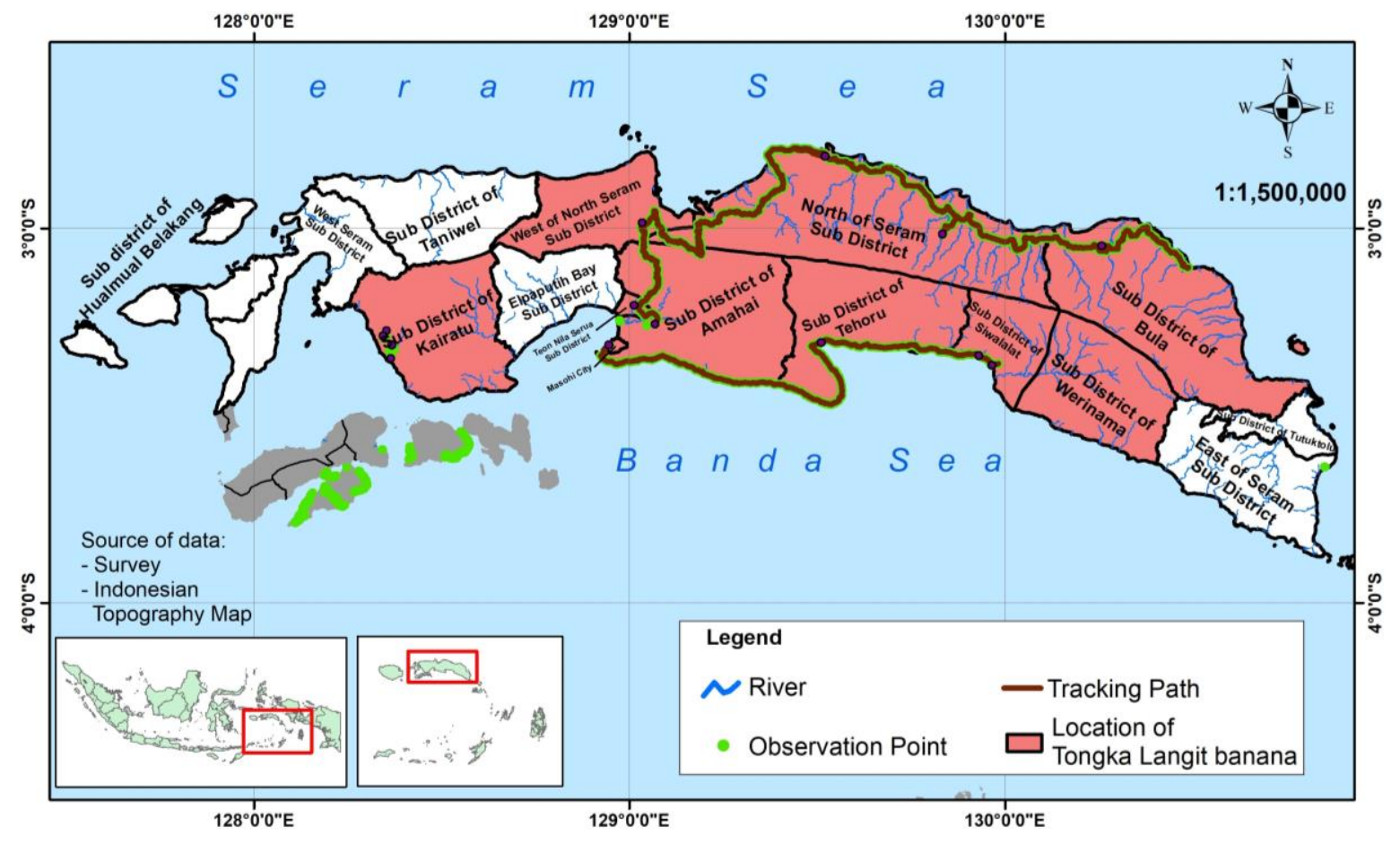

Figure 2. Tongka langit banana dispersion map in Seram Island 

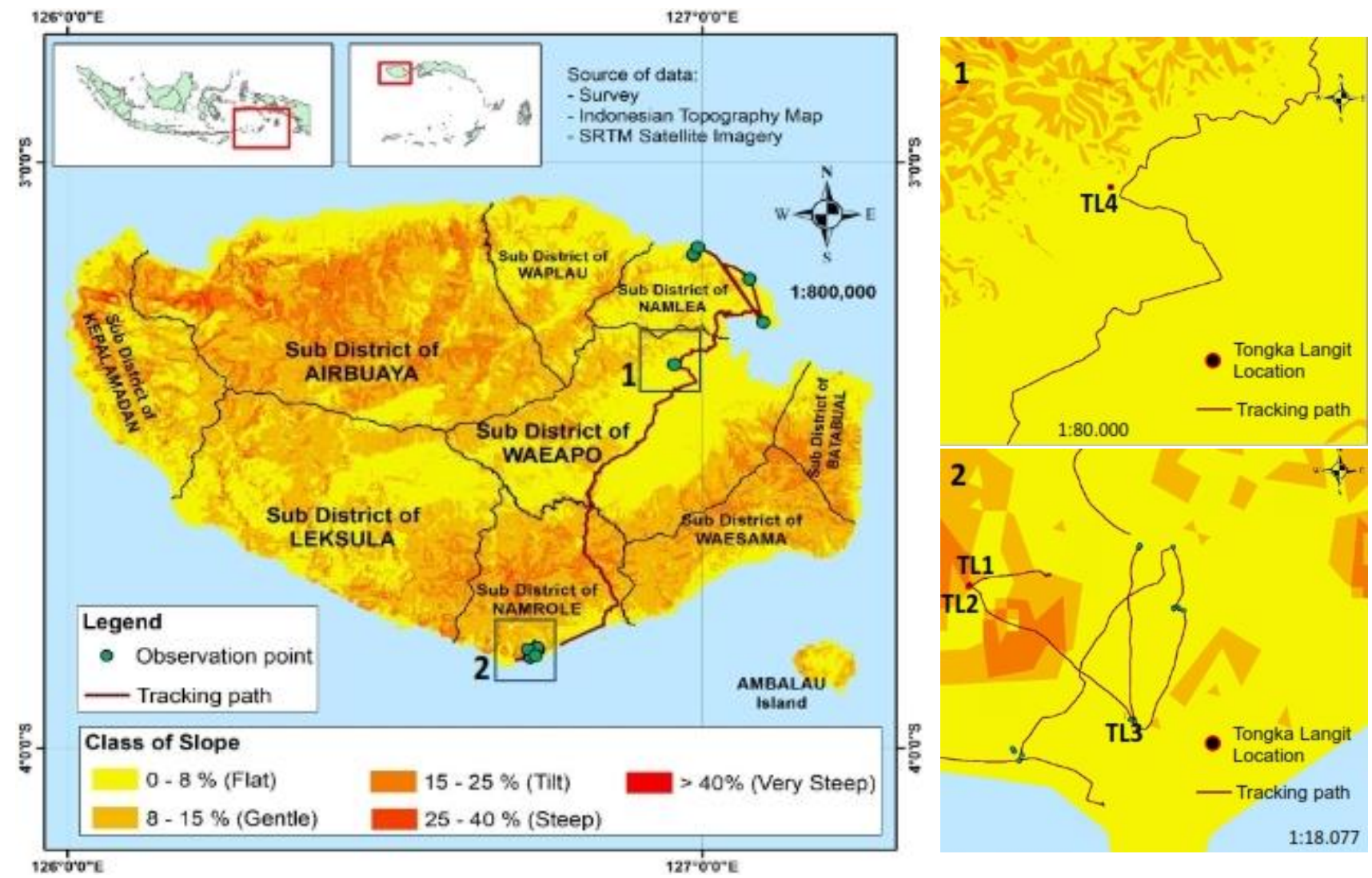

Figure 3. Slope map in Buru Island through the presence of tongka langit banana

Table 2. The coordinates tongka langit banana location in Buru Island and Seram Island
Table 3. Slope and contour on the tongka langit banana location in Buru and Seram Island

\begin{tabular}{|c|c|c|c|c|c|c|c|c|c|}
\hline Island & X & $\begin{array}{l}\text { dinate } \\
\text { Y }\end{array}$ & Sub-district & $\begin{array}{c}\text { No. of } \\
\text { location }\end{array}$ & Island & $\begin{array}{c}\text { Number of } \\
\text { Location }\end{array}$ & Slope $(\%)$ & $\begin{array}{r}\text { Contour } \\
(\mathrm{m} \text { asl. })\end{array}$ & $\begin{array}{c}\text { Alt. } \\
\text { (m asl.) }\end{array}$ \\
\hline \multirow[t]{4}{*}{ Buru } & 247371 & 9576101 & Namrole & TL 1 & Buru & TL 1 & $8-15$ & $0-300$ & 209 \\
\hline & 247377 & 9576115 & Namrole & TL 2 & & TL 2 & $8-15$ & $0-300$ & 209 \\
\hline & 248655 & 9574991 & Namrole & TL 3 & & TL 3 & $0-8$ & $0-300$ & 21 \\
\hline & 272779.559 & 9630036.1 & Waeapo & TL 4 & & TL 4 & $0-8$ & $0-300$ & 32 \\
\hline \multirow[t]{15}{*}{ Seram } & 592679.08 & 9666823.89 & North of Seram & TL 5 & Seram & TL 5 & $0-8$ & $0-300$ & 45 \\
\hline & 557905.96 & 9689726.78 & North of Seram & TL 6 & & TL 6 & $0-8$ & $0-300$ & 9 \\
\hline & 607201.505 & 9628009.11 & Siwalalat & TL 7 & & TL 7 & $0-8$ & $0-300$ & 11 \\
\hline & 556657.222 & 9634679.59 & Tehoru & TL 8 & & TL 8 & $0-8$ & $0-300$ & 6 \\
\hline & 607312.605 & 9628009 & Siwalalat & TL 9 & & TL 9 & $0-8$ & $0-300$ & 13 \\
\hline & 603426.85 & 9630887.04 & Siwalalat & TL 10 & & TL 10 & $0-8$ & $0-300$ & 14 \\
\hline & 428120.223 & 9638208.04 & Kairatu & TL 11 & & TL 11 & $0-8$ & $0-300$ & 39 \\
\hline & 427121.247 & 9636770.36 & Kairatu & TL 12 & & TL 12 & $0-8$ & $0-300$ & 22 \\
\hline & 429678.31 & 9634008.49 & Kairatu & TL 13 & & TL 13 & $0-8$ & $0-300$ & 35 \\
\hline & 429347.583 & 9630028.82 & Kairatu & TL 14 & & TL 14 & $0-8$ & $0-300$ & 12 \\
\hline & 507554.566 & 9640110.03 & Amahai & TL 15 & & TL 15 & $0-8$ & $0-300$ & 33 \\
\hline & 493890.024 & 9634030.76 & Masohi City & TL 16 & & TL 16 & $0-8$ & $0-300$ & 9 \\
\hline & 501333.225 & 9645747.49 & Teon Nila Serua & TL 17 & & TL 17 & $0-8$ & $0-300$ & 42 \\
\hline & 503667.132 & 9670285.83 & West of North Seram & TL 18 & & TL 18 & $8-15$ & $301-900$ & 361 \\
\hline & 639798.699 & 9663240.73 & Bula & TL 19 & & TL 19 & $0-8$ & $0-300$ & 25 \\
\hline
\end{tabular}

Note: $\mathrm{TL}=$ tongka langit . 


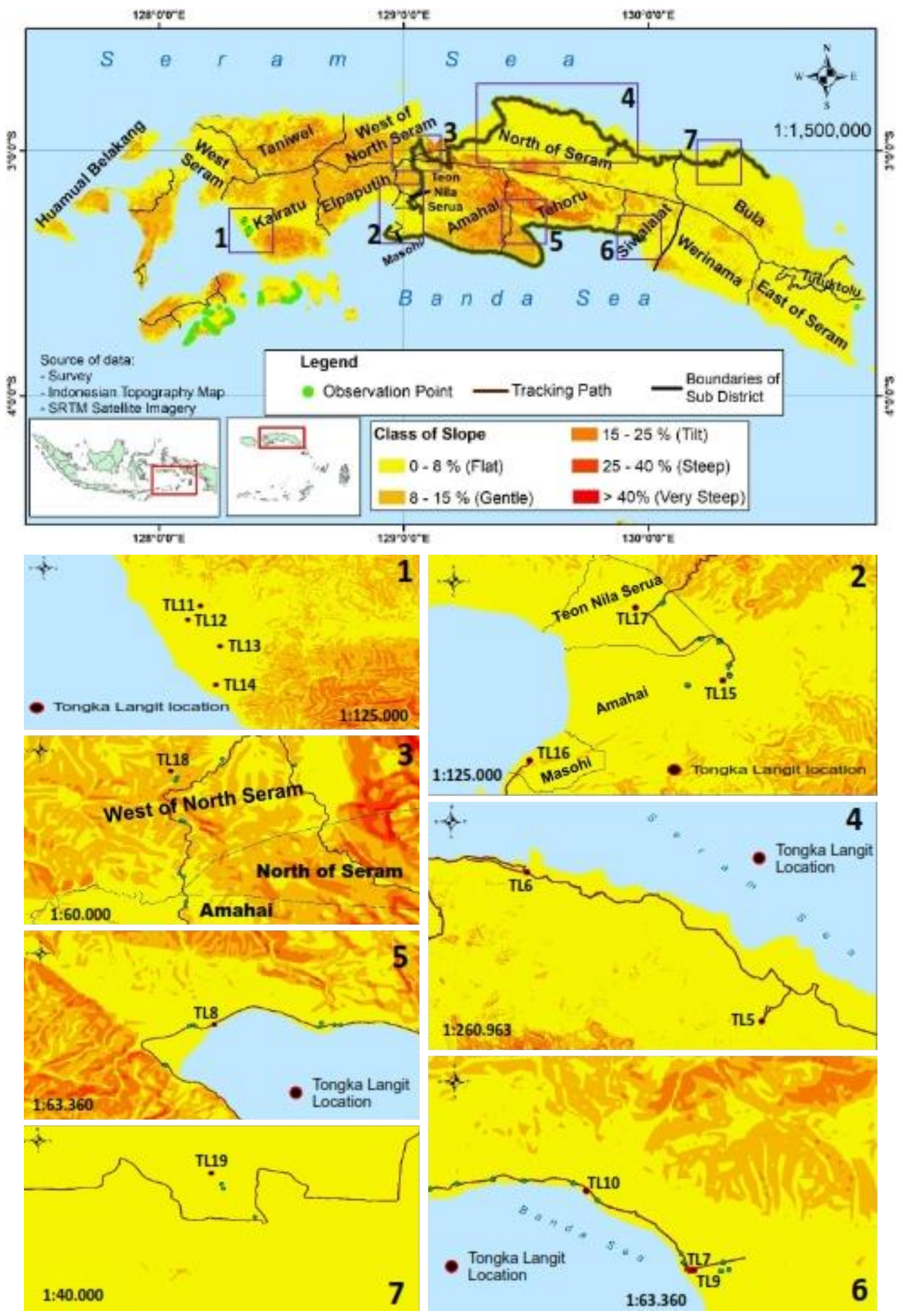

Figure 4. Slope map in Seram Island through the presence of tongka langit banana 
Table 4. Data on rainfall, rainy days, temperatures, humidity, wet months, dry months and humid months of Buru Island, Indonesia

\begin{tabular}{|c|c|c|c|c|c|c|}
\hline \multirow[t]{2}{*}{ Variable } & \multicolumn{5}{|c|}{$\begin{array}{c}\text { Buru Island } \\
\text { North of Buru and South of Buru } \\
\text { Year }\end{array}$} & \multirow[t]{2}{*}{ Average } \\
\hline & 2014 & 2015 & 2016 & 2017 & 2018 & \\
\hline Rainfall (millimeter / year) & 115 & 189.8 & 152.4 & 171.1 & 161.75 & 158.01 \\
\hline Rainy Days (days) & 131 & 134 & 152 & 189.5 & 137 & 148.7 \\
\hline Temperature ( ${ }^{\circ}$ Celcius) & 26.6 & 24.5 & 27.1 & 27 & 27.6 & 26.56 \\
\hline Humidity $(\%)$ & 84.4 & 84.08 & 87 & 86 & 81 & 84.49 \\
\hline Number of wet months * & 7 & 6 & 6 & 9 & 5 & 6.6 \\
\hline Number of dry months $*$ & 4 & 5 & 4 & 2 & 5 & 4 \\
\hline Number of humid months * & 1 & 1 & 2 & 1 & 2 & 1.4 \\
\hline
\end{tabular}

Note: Meteorology, Climatology, and Geophysical Agency. ${ }^{*}$ reference based on Mohr criteria classification about wet months with rainfall >100 millimeters; dry months with rainfall <60 millimeters; and humid months with rainfall 60-100 millimeter

Table 5. Data of rainfall, rainy days, temperatures, humidity, wet months, dry months and humid months of Seram Island, Indonesia

\begin{tabular}{|c|c|c|c|c|c|c|c|c|}
\hline \multirow[b]{2}{*}{ Location } & \multirow[b]{2}{*}{ Year } & \multicolumn{7}{|c|}{ Variable } \\
\hline & & $\begin{array}{c}\text { Rainfall } \\
\text { (millimeter/year) }\end{array}$ & $\begin{array}{l}\text { Rainy } \\
\text { days } \\
\text { (days) }\end{array}$ & $\begin{array}{l}\text { Temp. } \\
\left({ }^{\circ} \mathbf{C}\right)\end{array}$ & $\begin{array}{l}\text { Humidity } \\
\qquad \%)\end{array}$ & $\begin{array}{c}\text { Number of } \\
\text { wet months * }\end{array}$ & $\begin{array}{c}\text { Number of } \\
\text { dry months * }\end{array}$ & $\begin{array}{c}\text { Number of } \\
\text { humid months } \\
*\end{array}$ \\
\hline \multirow{6}{*}{$\begin{array}{l}\text { Seram (part o } \\
\text { Central Maluku) }\end{array}$} & 2014 & 246.8 & 230 & 27.4 & 86.9 & 8 & 4 & 0 \\
\hline & 2015 & 107.59 & 175 & 26.6 & 83.16 & 6 & 4 & 2 \\
\hline & 2016 & 207.32 & 187 & 27.3 & 84.33 & 8 & 2 & 2 \\
\hline & 2017 & 272.58 & 218 & 26.6 & 87.25 & 11 & 1 & 0 \\
\hline & 2018 & 195.95 & 234 & 26.76 & 85.83 & 9 & 2 & 1 \\
\hline & Average & 206.04 & 208.8 & 26.93 & 85.49 & 8.4 & 2.6 & 1 \\
\hline \multicolumn{3}{|c|}{ Seram (part of 2014} & \multicolumn{6}{|c|}{ Data not available for 3 years, due to equipment failure } \\
\hline \multirow[t]{5}{*}{ Western Seram) } & 2015 & 139.81 & 157 & 26.4 & 84 & 7 & 4 & 1 \\
\hline & 2016 & 159.8 & 216 & 27.23 & 85.33 & 9 & 2 & 1 \\
\hline & 2017 & 273.75 & 257 & 26.8 & 87.83 & 11 & 0 & 1 \\
\hline & 2018 & 200.33 & 227 & 26.82 & 86.75 & 11 & 1 & 0 \\
\hline & Average & 193.42 & 214.25 & 26.81 & 85.97 & 9.5 & 1.75 & 0.75 \\
\hline Seram (part o & 2014 & 134 & 158 & 27 & 82 & 6 & 4 & 2 \\
\hline \multirow{5}{*}{ Eastern Seram) } & 2015 & 100.5 & 151 & 27.3 & 79 & 7 & 4 & 1 \\
\hline & 2016 & 199 & 192 & 27.61 & 89.75 & 10 & 0 & 2 \\
\hline & 2017 & 198.97 & 177 & 29 & 87.75 & 10 & 0 & 2 \\
\hline & 2018 & 183.7 & 181 & 28.71 & 83.67 & 7 & 5 & 0 \\
\hline & Average & 163.23 & 171.8 & 27.92 & 84.43 & 8 & 2.6 & 1.4 \\
\hline $\begin{array}{l}\text { Average in } \\
\text { Seram Island }\end{array}$ & & 187.56 & 198.28 & 27.22 & 85.30 & 8.63 & 2.31 & 1.05 \\
\hline
\end{tabular}

Based on the Schmidt-Fergusson climate classification, Buru Island is in a rather wet climate zone, while Seram Island is in a wet climate zone, where the results are obtained from the calculation of $Q$ value that refers to the Schmidt-Ferguson climate classification (Table 1).

The $Q$ value calculated for Buru Island was 0.60. Thus can be concluded that the climate type of Buru Island is classified into $\mathrm{C}$ type, with a rather wet characteristic. This outcome is not in line with the calculation according to Koppen climate division in which this area belongs to tropical wet climate maintaining tropical rainforest vegetation. That is a long warm climate with high humidity and high yearly rainfall (Tasirin and Langi 2012). This may be due to the effects of global climate change, one of the consequences of which is an uncertain seasonal pattern. It can happen if the rainy season is too long, or the dry season is too long with a long cycle affecting the climate of an area.

The same calculation was carried out for Seram Island and it resulted in the $\mathrm{Q}$ value of 0.26 . Therefore, the climate type in Seram Island is classified into B type with wet characteristic. Meanwhile, Van Steenis (1979) states that Seram has semi-ever wet climate without real dry season and is located in Eastern West end. The yearly rainfall ranges from $2,100 \mathrm{~mm}-4,500 \mathrm{~mm}$, and the smallest monthly rainfall is below $100 \mathrm{~mm}$. This climate condition enables tropical rainforest to grow in Seram. Tropical rainforest can make various habitats available (Kato 1990). 
Based on the studies in terms of topography and climate, it can be seen that the existence of the tongka langit banana in Buru and Seram Island (Figure 7) does not depend on the similarity of topographic conditions, or climate conditions that are almost the same, but more on human efforts to preserve them. Although, the geographic range, for example, may be influenced by adaptation to climatic factors affecting the reproduction and survival of individuals (McNaughton and Wolf 1979). However, the active spread factor still determines whether a species will be imported from another location, so it can be studied by how the survival of the species in a new environment is.

Tongkat Langit dispersion is one form of active distribution which also involves human intervention in the trial planting effort. Even though the topography and climate conditions are similar, the results of observations and information gathering in the field show that the introduction of the community to a plant species also influences the species' existence. The people of Seram Island tend to be very familiar with, and consume the tongka langit banana so that they will continue to plant, process and even spread it by themselves; however, not all people in Buru Island recognize it, so most of them do not tend to process or spread it,; except for people from Ambon and Seram Island, who come to Buru Island for work or marriage reasons. They are the people who know tongka langit banana and deliberately bring the seeds from Seram and Ambon (based on the information from the owner of tongka langit banana: three of the four tongka langit bananas found in Buru Island are the result of seeds brought from Ambon Island). This is a limiting factor resulting in the spread of tongka langit banana in Buru Island which is very limited compared to Seram Island, even though these two islands have almost similar topographic and climatic conditions.

In addition, the change of seasonal patterns in Buru Island which occurred in several locations resulted in the tendency to dry during the year, coupled with the frequent burning of forests and the land that is filled with eucalyptus plants (Melaleuca leucadendra); also, the large amount of uncontrolled land clearing has eliminated most of the forest land in this island. These observations are in line with Poulsen reports that most of the Buru area is initially covered by rainforest $\left(1,520 \mathrm{~km}^{2}\right)$, although the majority of these habitats have now been cleared or seriously degraded, with estimation $1,020 \mathrm{~km}^{2}$ remain which almost all have been modified (Poulsen 1998). Fires have dramatically changed many areas with fire-resistant trees (Melaleuca leucadendron) dominated, while the remnants of trees represent the original monsoon forest that was once widespread (Poulsen and Lambert 2000).
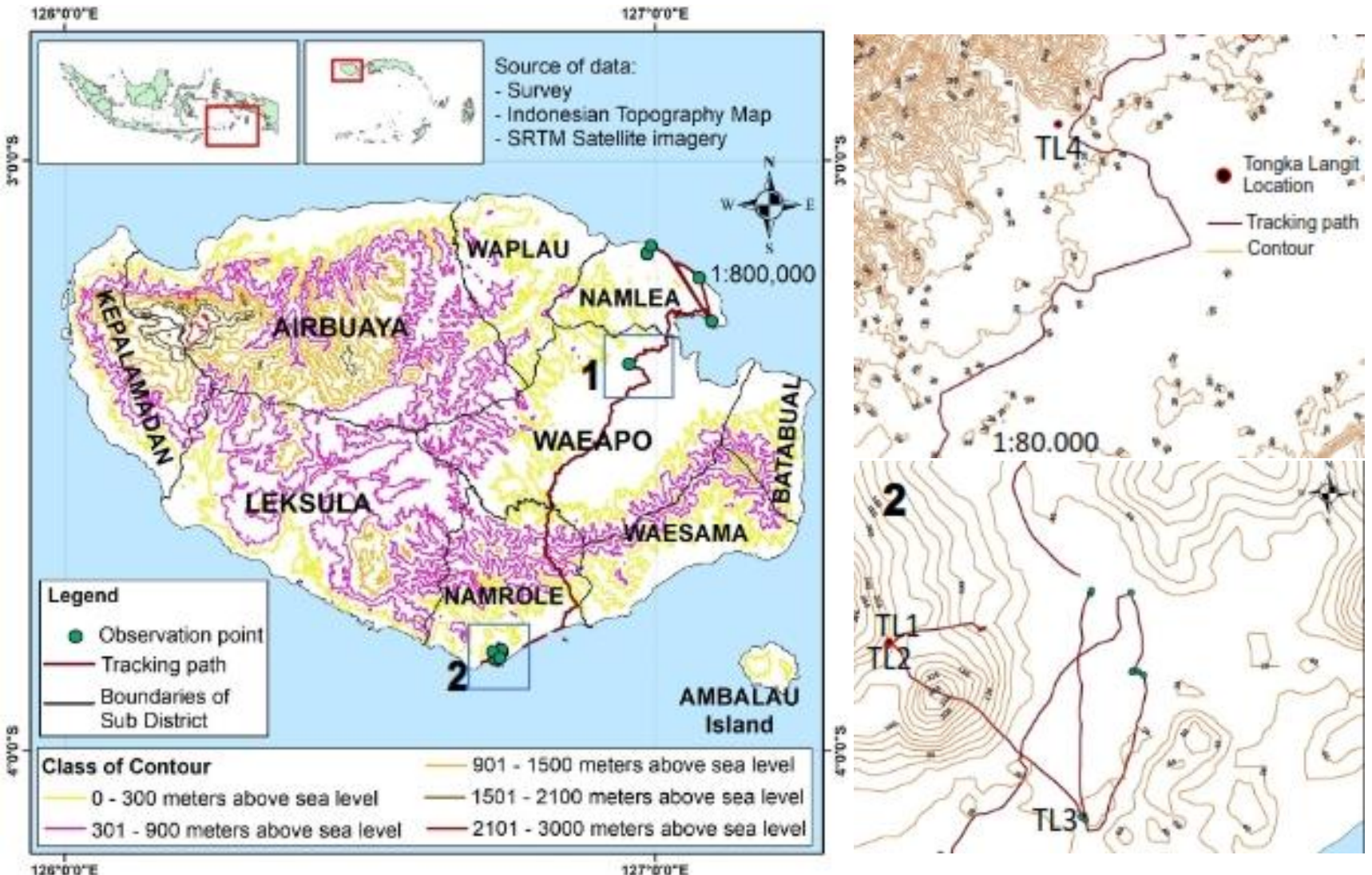

Figure 5. Contour map in Buru Island through the presence of tongka langit banana 

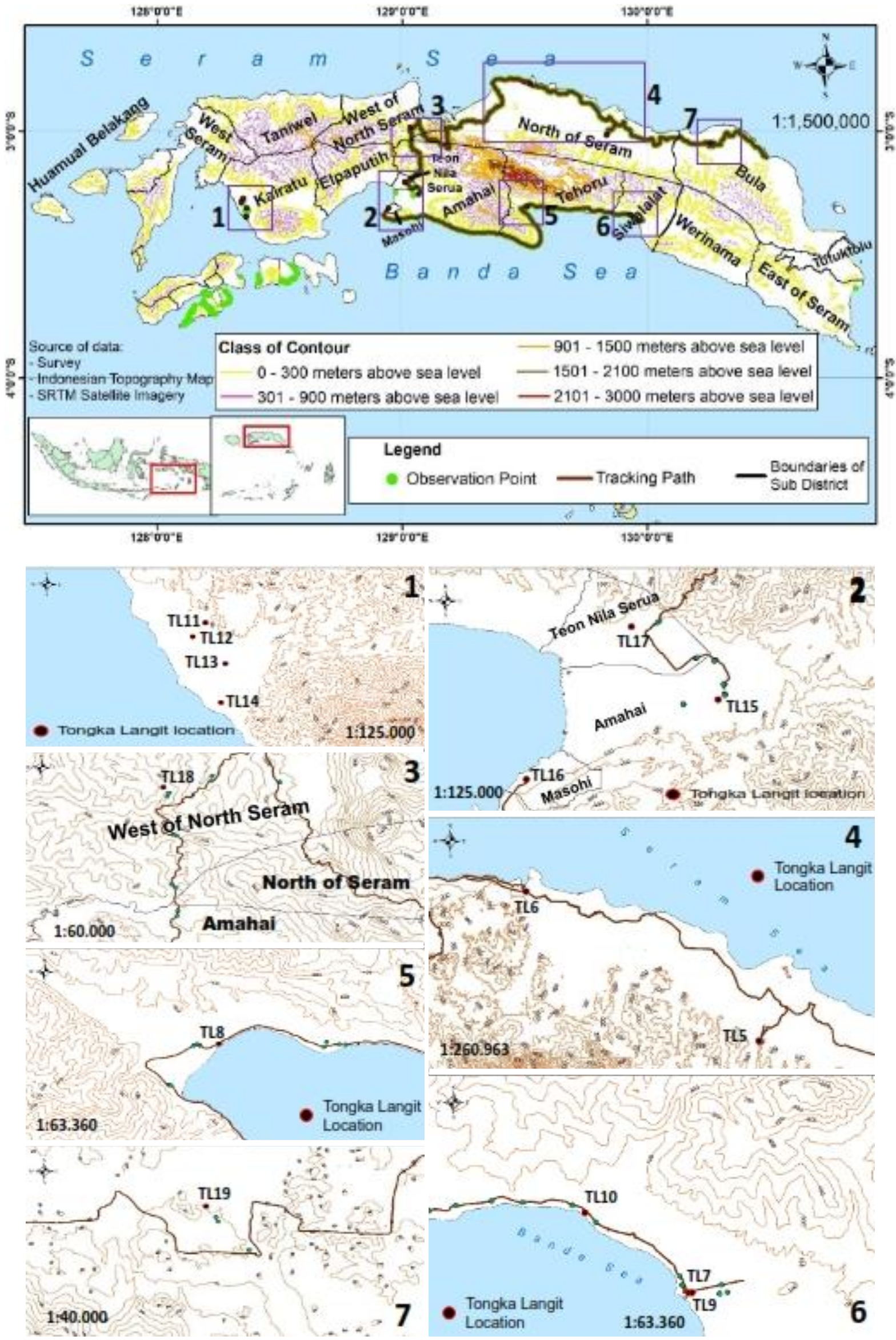

Figure 6. Contour map in Seram Island through the presence of tongka langit banana 

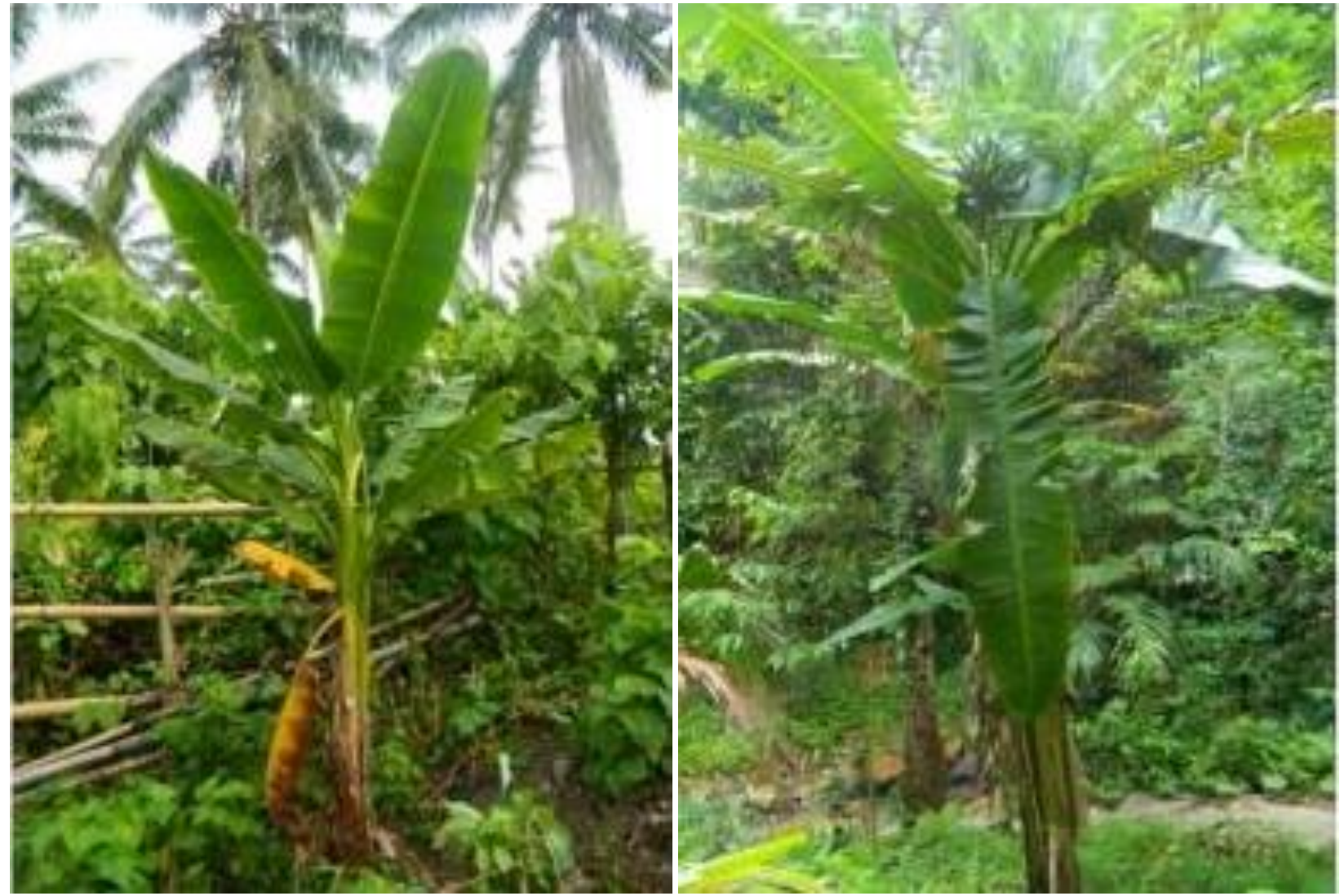

Figure 7. One of the tongka langit bananas found in Buru Island (left) and Seram Island (right)

\section{Discussion}

Referring to the slope and contour analysis result, the actual topography of Buru Island, an oval-shaped island with a predominantly mountainous region, surrounded by narrow flat areas, is located in coastal areas. In addition, there are varied heights in Buru Island from $0 \mathrm{~m}$ asl to the highest of 2,736 m asl on the summit of Mount Kaku Ghegan in the Kepala Madan Sub-district. Meanwhile, the other two mountains are Mount Rana in the middle, which is located in Air Buaya Sub-district with an altitude of 2,000 meters above sea level (m asl); and Mount Batabual to the East with an altitude of 1,731 $\mathrm{m}$ asl (Mubekti 2016). Based on another research, Buru Island possesses topography structure of hills and mountains which become parts of inner bows having complex geological structure as a consequence of movement of the Australian and Asian continental plates (Monk et al. 1997; Poulsen and Lambert 2000; Widodo et al. 2007). Buru Island is a non-volcanic region with four lithological units namely metamorphic, clay, terrace deposits and alluvium (Linthout et al. 1989; Rezky and Zarkasyi 2010). The highest point in Buru is Kepala Mada, or Head of Mada which continuously supports unbroken mountainous forest area (Poulsen and Lambert 2000; Shoedarto 2014).

Furthermore, according to the report of the Ministry of Energy and Mineral Resources, Republic of Indonesia, the Buru Island has mountainous morphology in the form of very steep slopes and many caves, hole (dolina), and underground rivers, some of which are in the form of mountain peaks namely Mount Kaku Date (1,576 m asl), Mount Kaku Mortinafina (1831 m asl), and Mount Kaku Ghegan (2,736 m asl); hilly morphology spread around that form a series of rounded hills and gentle slopes to steep, with covers about $40 \%$ of the island of Buru; while the landing morphology consists of lowlands and flat valleys between mountains, with lowlands lying on the north coast and along large rivers such as Waeapo, reaching $36 \mathrm{~km}$ in length and about $15 \mathrm{~km}$ in wide (Widodo et al. 2007). Specifically in locations where the tongka langit bananas were found, Namrole and Waeapo have various combined landforms, reliefs, altitude and geology material. It is formed from a combination of collovial plain landforms, karst hills and tectonic hills; with relief conditions rather flat, rather steep to steep; and covers an altitude range of less than $100 \mathrm{~m}$ asl to $700 \mathrm{~m}$ asl.The geology material is in the form of alluvium, limestone, sandstone, shale and clay (Mubekti 2016). Tongka langit Banana was found at three locations in Namrole with two adjacent locations in the mountains and with a rather tight contour composition. So that the conditions are rather steep, while the other location is in a residential area where the contour of the area is flat. Whereas, in Waeapo, the landform consists of alluvial plains, tectonic plains and tectonic hills; with relief conditions rather flat, wavy and steep; and covers an elevation range from $0 \mathrm{~m}$ asl to $700 \mathrm{~m}$ asl. The geology material is in the form of alluvium, schist, napal, quartzite, shale, sandstone and gneiss (Mubekti 2016). Tongka langit banana found in Waeapo was in a residential area, in the 
form of a gentle slope formed from fractures of structural formations. Meanwhile, most of Buru areas initially belong to rainforest with dense canopy and dense primary forest with high humidity. However, in the beginning of 1990s, serious degradation took place with the division of forest into preservation forest and production forest (Collins et al. 1991; Shoedarto 2014).

Based on previous research, the topography of Seram Island is mountainous with various heights including Binaiya Mountain with more than 3,000 $\mathrm{m}$ asl height (the highest peak in Maluku Archipelago) in which geologically functions as the center of Seram Island marked by the dominant formation of limestone, because most of them origin from peak zone (2,500-3,000 m asl) which are exposed to limestone and thin earthen stone (Jacobs 1988; Kato 1990). Seram Island has limestone formation which has gone through various natural processes in geological time scale. Seram Island owns mountainous geomorphology with dense forest in which most of Seram Island consists of steep slopes and deep valleys (Tjokrosapoetro and Budhitrisna 1982; O'Sullivan et al. 1985). The condition of the plains, in general, is wavy with variations of slope from leaning to steep (Audley-Charles et al. 1979). Meanwhile, the lithology consists of alluvial stone, conglomerate stone, limestone, volcanic breccia, schist (metamorphic), tufa (volcanic sediment), andesite (igneous rock), marl (mechanical sediment), limestone and sandstone (Audley-Charles et al. 1979; Tjokrosapoetro and Budhitrisna, 1982; O'Sullivan et al. 1985; Audley-Charles 1986).

Results of the SRTM analysis supports the true condition of Seram Island. Seram Island has a complex mountain structure and various types of coastal landscapes. The contour and slope map (Figure 4 and 6) shows that the tongka langit banana was found in various forms of structural and denudational to alluvial reliefs. In Kairatu, tongka langit banana was found in a location close to the coast, with a topographic altitude range that is not too high , i.e. above 10 meters above sea level and nearly 40 meters above sea level, with location conditions limited by hilly areas with structural fractures. In Amahai, the location of the tongka langit found is in a sloping area resembling a valley surrounded by the formation of structural faults, and far from the coast; while at the location of the Teon Nila Serua, tongka langit banana found was also far from the coast, and was in a fairly gentle location that was limited by a broken structural composition, but with a higher altitude than that found in Amahai. At the location in Masohi, tongka langit banana was found quite close to the coast, but located right on the ridge facing the sea, which is quite sloping location. As for the location of the tongka langit banana found in Tehoru and Siwalalat, it is almost the same condition as that in Masohi, namely the condition of the area which is a ridge facing the sea. In Tehoru, it is found right on the farm land owned by residents close to the coast, and also close to the main road; while in Siwalalat, it is found in the location of residential areas, that is in the yard of their house, with the condition of the land being slightly bumpy because it is a ridge, and the further away from the beach, the condition of the land is increasingly bumpy.

Tongkat Langit banana was found in three sub-districts of Northern part of Seram Island i.e., North of Seram Subdistrict, West of North Seram Sub-district, and Sub-district of Bula. In the North of Seram Sub-district, tongka langit banana was found in the end area of a series of structural faults, or can also be called as the end area of a valley that is almost close to the coast. In the West of North Seram Sub-district, tongka langit banana was found in the mountains with a high altitude of $361 \mathrm{~m}$ asl, with a fractured and somewhat dense structural formation. In Subdistrict of Bula, tongka langit banana was found in the valley area which is a former hilly fracture. Based on the geological map of Seram Island, Northern Seram consists of metamorphic rocks, alluvium, Seram rocks formation and Australian rocks formation. The North West Seram, Bula, Siwalalat and Tehoru consist of alluvium rocks, Seram rocks formation and Australian rocks formation, whereas in the Amahai and Masohi, the metamorphic rocks are dominant; and the Teon Nila Serua and Kairatu are dominated by metamorphic rocks and alluvium.

In conclusion, with almost the same topography and climate conditions on both islands, the findings of the existence of tongka langit banana are not always the same. Tongka langit bananas were found in Seram Island is more dominant than those of found in Buru Island. In both islands, the slope for tongka langit banana growth is dominantly between $0-8 \%$ and less than $50 \mathrm{~m}$ asl altitude.In Seram Island with wet climatic conditions (Type B Schmidt-Ferguson climate classification), tongka langit banana was found in fifteen locations; while, in Buru Island with rather wet climate conditions (Type C SchmidtFerguson climate classification), tongka langit banana was found in four locations. It is suggested that the limiting factor for the spread of this species is not the topographic and climatic conditions, but the active dispersion factor.

\section{ACKNOWLEDGEMENTS}

We are hereby thank you to Universitas Pattimura, Ambon, Indonesia for the research fund through platform DIPA with letter number 1420/UN13/SK/2018; and also to Center of Spatial Data Infrastructure Development, Universitas Pattimura; and the deepest gratitude to the local people in Buru and Seram that very helpful at the time, so we can manage to fulfill all the schedule.

\section{REFERENCES}

Ahern J. 1999. Spatial concepts, planning strategies, and future scenarios: a framework method for integrating landscape ecology and landscape planning. In: Klopatek J, Gardner R (eds.). Landscape Ecological Analysis. Springer, New York.

Amos CB, Burbank DW, Read SA. 2010. Along-strike growth of the Ostler fault, New Zealand: Consequences for drainage deflaction above active thrusts. Tectonics 29 (4): 1-33.

Aronoff S. 1991. Geographic information systems: a management perspective. WDL Publications. 
Arvanitoyannis IS, Mavromatis AG, Grammatikaki-Avgeli G, Sakellariou M. 2015. Banana: cultivars, biotechnological approaches and genetic transformation. Intl J Food Sci Technol 43 (10): 1871-1879.

Audley-Charles MG, Carter DJ, Barber AJ, Norvick MS, Tjokrosapoetro S. 1979. Reinterpretation of the geology of Seram: Implications for the Banda Arc and Northern Australia. J Geol Soc London 136: $547-$ 568.

Audley-Charles MG. 1986. Timor-Tanimbar Trough: the foreland basin to the evolving Banda orogen. In: Allen PA, Homewood P, Williams GD (eds.) Foreland Basins. Blackwell Scientific Publications, London.

Baggio RA, Stoiev SB, Spach HL, Boeger WA. 2017. Opportunity and taxon pulse: thr central influence of coastal geomorphology on genetic diversification and endemism of strict estuarine species. J Biogeography 44 (7): 1626-1639.

Bertoia ML, Mukamal KJ, Cahill LE, Hou T, Ludwig D, Mozaffarian D, Rimm EB. 2015. Changes in intake of fruits and vegetables and weight change in United States men and women followed for up to 24 years: analysis from three prospective cohort studies. PLOS Medicine. DOI: 10.1371/journal.pmed.1001878

Campbell G, Norman J. 2012. An introduction to environmental biophysics. Springer Science \& Business Media, New York.

Collins NM, Sayer JA, Whitmore TC. 1991. The Conservation Atlas of Tropical Forest: Asia and the Pacific. Palgrave Macmillan, London.

Croce A, Stinca A, Santangelo A, Esposito A. 2019. Exploring vascular flora diversity of two protected sandy coastal areas in southern Italy. Rendiconti Lincei. Scienze Fisiche e Naturali 30: 323-336.

De Langhe E, de Maret P. 1999. 20 Tacking the banana: its significance in early agriculture. In: Gosden C, Hather JG (eds.). The prehistory of food. Taylor and Francis group, London.

Drapal M, de Carvalho EB, Rouard M, Amah D, Sardos J, Van den Houwe I, Brown A, Roux N, Swennen R, Fraser PD. 2019 Metabolite profiling characterises chemotypes of Musa diploids and triploids at juvenile and pre-flowering growth stages. Sci Rep 9 (1): 1 10.

ESRI. 1999. Getting to know ArcView GIS: the geographic information system (GIS) for everyone. Vol. 1. 3rd ed. Redlands, California.

Franklin J. 1995. Predictive vegetation mapping: geographic modelling of biospatial patterns in relation to environmental gradients. Progr Physic Geogr 19 (4): 474-499.

Gibson DJ, Hulbert LC. 1987. Effects of fire, topography and year-to-year climatic variation on species composition in tallgrass prairie. Vegetatio 72 (3): 175-185.

Hiariej A, Arumingtyas EL, Widoretno W, Azrianingsih R. 2015. Genetic kinship of tongka langit banana (Musa troglodytarum L.) from Mollucas based on rbcL gene sequence. Indian J Genet Plant Breed 75 (4): 526-528.

Hiariej A, Karuwal RL. 2015. Profil Lingkungan Tumbuh Pisang tongka langit (Musa troglodytarum L.) Di Kabupaten Maluku Tengah. BioWallacea Jurnal Ilmiah Ilmu Biologi 1 (1): 59-63. [Indonesia]

Hillel D. 2007. Soil in the environment: crucible of terrestrial life. Elsevier, Nederland.

Horry J, Jay M. 1988. Distribution of anthocyanins in wild and cultivated banana varieties. Phytochemistry 27 (8): 2667-2672.

Indonesia Central Statistics Agency. 2017. Production of Fruits. https://www.bps.go.id/site/resultTab

Jacobs M. 1988. The Tropical Rain Forest. Springer Verlag, Berlin.

Jin XH, Cao L, Zang YG. 2013. Spatial distribution of tree species richness in Xiaodonggou forest region of the Altai Mountains, Northwest China. Acta Ecol Sin 33 (9): 2286-2895.

Kato M. 1990. The fern flora of Seram. In: The Plant Diversity of Malesia: Proceedings of the Flora Malesiana Symposium commemorating Professor Dr. CGGJ Van Steenis in Leiden, August 1989. Springer Science \& Business Media, New York.

Lakitan B. 2002. Dasar-Dasar Klimatologi. PT Raja Grafindo Persada, Jakarta. [Indonesian]

Latupeirissa Y, Nawangsih AA, Mutaqin KH. 2014. Selection and identification of bacteria from tongka langit banana (Musa troglodytarum L.) to control the blood disease bacteria. J Intl Soc Southeast Asian Agric Sci 20 (2): 110-120

Leitch M, Miller S. 2017. Optimizing wood utilization based on whole tree inherent property maps. In: Pandey KK, Ramakantha V, Chauhan SS, Kumar ANA (eds.) Wood is Good. Springer Nature, Singapore.
Lillesand TM, Kiefer RW. 2004. Remote Sensing and Image Interpretation. 6th ed. Wiley, Amsterdam.

Linthout K, Helmers H, Sopaheluwakan J, Nila ES. 1989. Metamorphic complexes in Buru and Seram, northern Banda arc. Netherlands J Sea Res. DOI: 10.1016/0077-7579 (89)90160-9

McNaughton SJ, Wolf LL. 1973. General Ecology, 2nd ed. Holt, Rinehart and Winston, USA.

Monk KA, de Fretes Y, Lilley GR. 1997. The Ecology of Nusa Tenggara and Maluku. 5th ed. Periplus Edition, Singapore.

Mubekti M. 2016. Karakterisasi sumberdaya lahan dan pewilayahan komoditas unggulan perkebunan di Pulau Buru. Jurnal Teknologi Lingkungan 12 (3): 309-318. [indonesian]

O’Sullivan TD, Pegum D, Tarigan J. 1985. Seram oil search, past discoveries and future oil potential. In: Indonesian Petroleum Association. 14th Annual Convention Proceedings, 1985.

Padam BS, Tin HS, Chye FY, Abdullah MI. 2014. Banana by-products: an under-utilized renewable food biomass with great potential. J Food Sci Technol. DOI: 10.1007/s13197-012-0861-2

Pereira A, Maraschin M. 2015. Banana (Musa spp.) from peel to pulp: ethnopharmacology, source of bioactive compounds and its relevance from human health. J Ethnopharmacol 160: 149-163.

Ploetz R, Pegg K. 1997. Fusarium wilt of banana and Wallace's line: Was the disease originally restricted to his Indo-Malayan region? Australasian Plant Pathol 26 (4): 239-249.

Poole HL, Mukaromah L, Kobryn HT, Fleming PA. 2015. Spatial analysis of limiting resources on an island: diet and shelter use reveal sites of conversation importance for the Rottnest Island quokka. WIldlife Res 41 (6): 510-521.

Poulsen MK, Lambert FR. 2000. Altitudinal distribution and habitat preferences of forest birds on Halmahera \& Buru, Indonesia: Implications for conservation of Moluccan Avifaunas. Intl J Avian Sci 142 (4): 566-586.

Poulsen MK,1998. Biodiversity conservation priorities. In: Buru with special reference to the proposed Kapalat Mada Wildlife Sanctuary. PHPA/Birdlife, International-Indonesia programme, Bogor

Rezky Y, Zarkasyi A. 2010 Indication of Intrusive Body in Wapsalit Geothermal Area, Buru Island, Indonesia. In: World Geothermal Congress, Bali, 25-29 April 2010.

Romanov AA, Koroleva EG, Dikareva TV. 2017. Integration of species and ecosystem monitoring for selecting priority areas for biodiversity conservation: Case studies from the Palearctic of Russia. Nat Conserv 22: 191-218.

Samson E, Semangun H, Rondonuwu FS. 2013. Analysis of carotenoid content of crude extract of tongka langit banana fruit (Musa troglodytarum L.) using NIR spectroscopy. Trad Med 18 (1): 17-21.

Severin DHI, Harter DE, Steinbauer MJ, Gallego Puyol D, Fernández-Palacios JM, Jentsch A, Beierkuhnlein C. 2015. Climate vs. topography-spatial patterns of plant species diversity and endemism on a high-elevation island. J Ecol 103 (6): 1621-1633.

Shoedarto RM. 2014. Pre Feasibility Study for Agricultural Drying Projects In Buru Island, Maluku. In: The New Zealand Geothermal Workshop, Auckland.Tasirin JS, Langi MA. 2012. Geografi Tanaman di Bioregion Wallace. Tropical Plant Curriculum Project. Universitas Sam Ratulangi, Manado and A\&M University, Texas.

Tjokrosapoetro S, Budhitrisna T. 1982. Geology and Tectonics of Northtern Banda Arc. Bull Geol Res Dev Centre 6: 1-17.

Van Steenis CGGJ. 1979. Plant-geography of east Malesia. Bot J Linn Soc 79 (2): 97-178.

Wango TL, Musiega D, Mundia CN, Altmann J, Alberts SC, Tung J. 2019. Climate and Land Cover Analysis Suggest No Strong Ecological Barriers to Gene Flow in a Natural Baboon Hybrid Zone. Intl J Primatol 40 (1): 53-70.

Widodo S, Sulaeman B, Sumardi E, Lim D. 2007. Potensi panas bumi wilayah Kabupaten Buru Maluku. Buletin Sumberdaya Geologi Pusat Sumberdaya Geologi 2 (1): 91-98. [Indonesian]

Woellner R, Wagner TC. 2019. Saving species, time and money: Application of unmanned aerial vehicles (UAVs) for monitoring of an endangered alpine river specialist in a small nature reserve. Biol Conserv 233: 162-175.

Yusuf NAAN, Yusoff M, Bakar BA, Ali A, Ameran N, Razab MKAA, Rus A, Marsi N, Sulong N. 2019. Preparation of banana (Musa paradisiaca L.) peel as cellulose powder in hybrid polymer matrix: A review. AIP Conf Proc 2068: 020046. DOI: 10.1063/1.5089345. 